\title{
Scorpionism in east Minas Gerais: clinical and epidemiological aspects
}

\author{
Escorpionismo no leste de Minas Gerais: aspectos clínicos e epidemiológicos
}

\author{
Escorpionismo este de Minas Gerais: aspectos clínicos y epidemiológicos
}

Ione Maria de Matos ${ }^{1 *}$, Leandro Roberto de Macedo¹, Lívia Cristina Ramiro¹, Larissa Rocha Manhães Alves ${ }^{1}$, Jéssica Genoveva Boline Passarelli Capaz Pinto da Silva¹.

\begin{abstract}
Objective: To report scorpion stings that occurred in eastern Minas Gerais. Methods: Data were collected retrospectively from medical records of patients admitted by scorpionism in Municipal Hospital. Statistical analyses were performed using the characterization of the total cases through descriptive statistics, which was presented in absolute and relative frequencies. The study was approved by the Research Ethics Committee. Results: There were 4,618 cases of scorpion stings, with the highest incidence from October to December. The males were more affected. The majority accidents were classified as mild occurrences. Local pain was reported in $98.04 \%$ of cases. The elapsed time between the accident and medical care varied mostly between 0-3 hours, the upper limbs were the most affected area. There was a total of 12 deaths predominantly in the 1-14 age group that presented systemic complications, with the cause of death being acute pulmonary edema and/or shock. Conclusion: The variables age, the elapsed time between the accident and medical care and the severity of symptoms played a pivotal role in death after poisoning by scorpion sting.
\end{abstract}

Keywords: Scorpion, Venom, Envenomation, Epidemiology.

\section{RESUMO}

Objetivo: Relatar dados sobre as picadas de escorpião ocorridas no leste de Minas Gerais. Métodos: Os dados foram coletados retrospectivamente em prontuários de pacientes internados com escorpionismo no Hospital Municipal. A caracterização do total de casos foi realizada por meio de estatística descritiva apresentada em frequências absolutas e relativas. Estudo aprovado pelo Comitê de Ética em Pesquisa. Resultados: Ocorreram 4.618 casos de picadas de escorpião, com maior incidência de outubro a dezembro. O sexo masculino foi mais afetado. A maioria dos acidentes foi classificada como leve e dor local foi relatada em $98,04 \%$ dos casos. O tempo decorrido entre $o$ acidente e o atendimento médico variou, em sua maioria, de 0 a 3 horas, sendo os membros superiores a região mais acometida. Foram registrados 12 óbitos, predominantemente na faixa etária de 1 a 14 anos, que apresentaram complicações sistêmicas, sendo a causa da morte edema agudo de pulmão e / ou choque. Conclusão: As variáveis, idade, gravidade dos sintomas, tempo decorrido entre o acidente e o atendimento médico, tiveram papel fundamental na morte após envenenamento por picada de escorpião.

Palavras-chave: Escorpião, Veneno, Envenenamento, Epidemiologia.

\section{RESUMEN}

Objetivo: Reporte datos sobre picaduras de escorpión ocurridas en el este de Minas Gerais. Métodos: Se recolectaron datos retrospectivamente de las historias clínicas de pacientes hospitalizados con escorpiones en el Hospital Municipal. La caracterización del número total de casos se realizó mediante estadística descriptiva presentada en frecuencias absolutas y relativas. Estudio aprobado por el Comité de Ética en Investigación. Resultados: Hubo 4.618 casos de mordeduras, con mayor incidencia de octubre a diciembre. El sexo masculino se vio más afectado. La mayoría de los accidentes se clasificaron como leves y se notificó dolor local en el 98,04\% de los casos. El tiempo transcurrido entre el accidente y la asistencia médica osciló, en la mayoría de los casos, de 0 a 3 horas, siendo los miembros superiores la región más afectada. Se registraron 12 defunciones, predominantemente en el grupo de edad de 1 a 14 años, que presentaron complicaciones sistémicas, siendo la causa de muerte edema agudo de pulmón y / o shock. Conclusión: Las variables edad, gravedad de los síntomas, tiempo transcurrido entre el accidente y la atención médica, jugaron un papel fundamental en la muerte por intoxicación por picadura de escorpión.

Palabras clave: Escorpión, Veneno, Envenenamiento, Epidemiología.

${ }^{1}$ Universidade Federal de Juiz de Fora (UFJF-GV), Governador Valadares - MG. *E-mail: ione.matos@ufjf.edu.br 


\section{INTRODUCTION}

Scorpion stings are considered a global medical-sanitary problem in many tropical and subtropical countries and are recognized by the World Health Organization (WHO) as an emerging public health problem that is sometimes neglected (CHIPPAUX JP and GOYFFON M, 2008; WHO, 2007). In Brazil, are registered about 50 thousand cases per year by stings of scorpion with an increase in incidence in the warmer periods (MINISTÉRIO DA SAÚDE, 2017; RECKZIEGEL GC and PINTO VL, 2014).

The Tityus genus is of medical importance, and the common species are the Tityus serrulatus and $T$. bahiensis, among them, $T$. serrulatus raises more concern as accidents with such species tend to be more severe. The spatial distribution of this species encompasses a few regions in Minas Gerais, São Paulo, Rio de Janeiro, Bahia, and Espírito Santo. Nevertheless, accidents with this type of scorpion are reported all over Brazil. From 2007 until 2017, the incidence increased from 12,552 to 124,077, totaling 951,727 cases (MINISTÉRIO DA SAÚDE, 2017).

A high number of scorpion envenomation happen because of the sting of the $T$. serrulatus. Its venom can cause malfunction of the major physiological systems especially in children and elderly individuals. In most severe cases of scorpion envenomation, respiratory distress syndrome, also reported as pulmonary edema may be the cause of death as well as it is a frequent finding in patients stung by that scorpion, especially among children, in whom the number of severe cases and the lethality rate are increased (CAMPOS JA, et al., 1979, 1980; AMARAL CFS, et al., 1993; DE MATOS IM, et al., 1997; RECKZIEGEL GC and PINTO VL, 2014; AMARAL CFS, et al.,1993; DESHPANDE SB and AKELLA A, 2012; PUCCA MB, et al., 2015).

The pulmonary pathogenesis caused by scorpion envenomation is extremely complex because it results from cardiogenic and noncardiogenic mechanisms. Among the cardiogenic factors, there are arterial hypertension, increased venous return, and myocardial dysfunction (AMARAL CFS, et al., 1993). The noncardiogenic mechanisms are a result of vasoactive substances that might lead to increased vascular permeability (DE MATOS IM, et. al., 1997). Patients stung by scorpions develop a systemic inflammatory response and the release of cytokines plays a major role in the pathogenesis of this inflammatory response (ISMAIL M, 1995; ZOCCAL KF, et al., 2014).

Furthermore, Tityus serrulatus scorpion venom induces cytotoxic effects on human bronchial epithelial cells, involving necrosis and release of pro-inflammatory cytokines, IL-1b, IL-6 and IL-8 (RIGONI VLS, et al., 2016). Scorpionism in Brazil is a serious public health problem despite great efforts of the Ministry of Health to control scorpion populations and the steady increase in scorpion stings. Recently, PIMENTA RJG, et al., 2019 demonstrated that access to water plays a fundamental role in the survival of $T$. serrulatus because reproduction occurs throughout the year even in the absence of food but does not occur in the absence of water. Incidents reported in Minas Gerais and São Paulo represent half of all cases in the country. Scorpion accidents in Minas Gerais increased from 1,189 cases in 2000 to 27,955 in 2017, reaching a total of 223,033 cases, with an incidence of 6.7 per 10,000 inhabitants in 2000 and 132.4 per 10,000 in 2017 (MINISTÉRIO DA SAÚDE, 2017).

Studies on profiling accidents caused by scorpions in east Minas Geras are still scarce. This study aims to describe and assess the scorpion accidents reported and treated in a public hospital in east Minas Gerais, from January 2007 to December 2016. This Hospital is an intermunicipal reference for the treatment of patients afflicted by scorpion envenomations, receives and provides care for patients from 86 cities in its region (COSTA BC, 2011).

\section{METHODS}

\section{Study area}

The study was carried out in a public hospital in the eastern region of Minas Gerais, southeastern Brazil. This hospital is located in a city in the valley of the Vale do Rio Doce, at an average altitude ranging from 250 to 500 meters above sea level and it has a semi-humid hot tropical climate, with an average annual temperature 
of $24^{\circ} \mathrm{C}$ (IBGE, 2014). Its population was estimated at 279,885 inhabitants, covering a geographical area of 2,342,325 km², with a demographic density of 119.5 inhabitants / Km² (IBGE, 2019).

\section{Data Acquisition}

This retrospective epidemiological study was approved by the Ethics Committee of the Biological Sciences of the Federal University of Juiz de Fora - under the inscription number 1,698,173. Data were collected from all medical records of patients showing a diagnosis of scorpionism hospitalized in a public hospital in the eastern region of Minas Gerais, from January 2007 to December 2016. The analysis of the medical records was authorized by written consent of the hospital's administration, upholding the confidentiality of patients.

Epidemiological data were analyzed according to the local and systemic clinical manifestations, age, gender, year and month of the scorpion sting, zone of occurrence, part of the body stung, and time elapsed between sting and medical assistance. The severity of the clinical manifestations is related to the envenomation intensity that can be classified, according to the Ministry of Health, as mild (local pain), moderate (local pain or vomiting, agitation, prostration or malaise, sudoresis, tachypnea, tachycardia, and mild arterial hypertension), or severe (including moderate symptoms plus heart failures, pulmonary edema, and shock) (MINISTÉRIO DA SAÚDE, 2001). Statistical analyses were performed using the characterization of the total cases through descriptive statistics, which was presented in absolute and relative frequencies.

The variables with the normal distribution were as mean \pm standard deviation. Variables that did not have a normal distribution were corrected as median followed by first and third quartile. To estimate the occurrence rate per 100,000 inhabitants from 2007 to 2016, a linear regression model of the number of accidents per 100000 inhabitants $(\mathrm{X})$ per year $(\mathrm{Y})$ was adjusted. considering the number of accidents in each year and the respective population estimate in each year (IBGE, 2019).

\section{RESULTS}

There were 4,618 hospital admissions by scorpionism between January 2007 and December 2016, of which 3,900 occurred in the municipality of Governador Valadares, and 705 incidents were from the nearby regions. There are some seasonal fluctuations with significant peaks in October, November, and December and decrease in March, April, May, and June. The majority of accidents (65\%) were classified as mild, $18 \%$ as moderate, $2 \%$ as severe and $15 \%$ were not identified. Male victims were most afflicted in the 2007-2015 period, while a higher incidence of female victims was observed in 2015 and 2016 (Figure 1).

Figure 1 - Number of accidents with male and female victims in the period from 2007 until 2016.

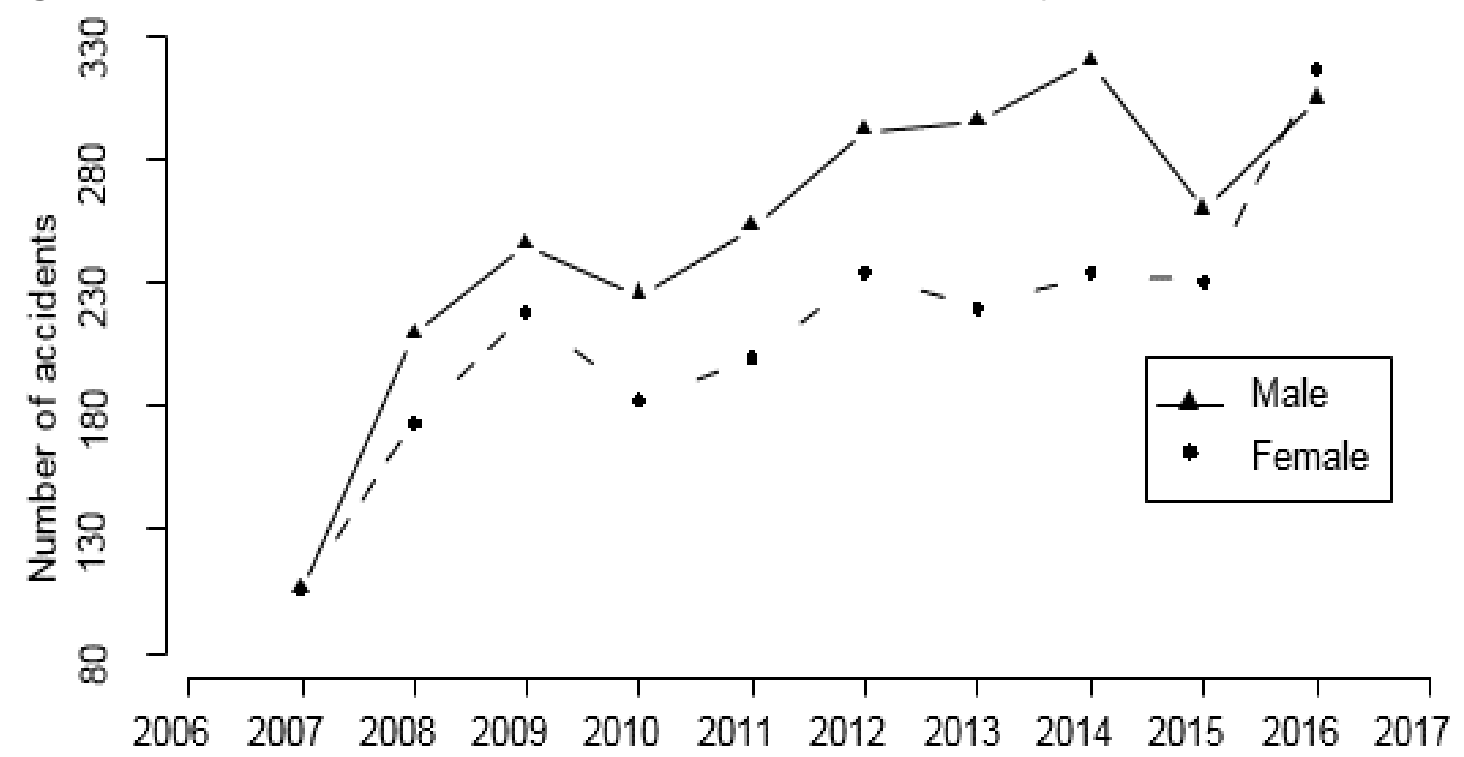

Source: De Matos IM, et al., 2020.

The frequency of cases in relation to the age group ranged from 0 to 107 years, with an average of 32.5 years and a median of 30 with first and third quartile $(13-50)$. The most victims $(n=106)$ were aged 10 years. In the medical records, the species of the aggressor was not identified (Figure 2). 
Figure 2 - Frequency of accidents in relation to the age group from 2007 to 2016.

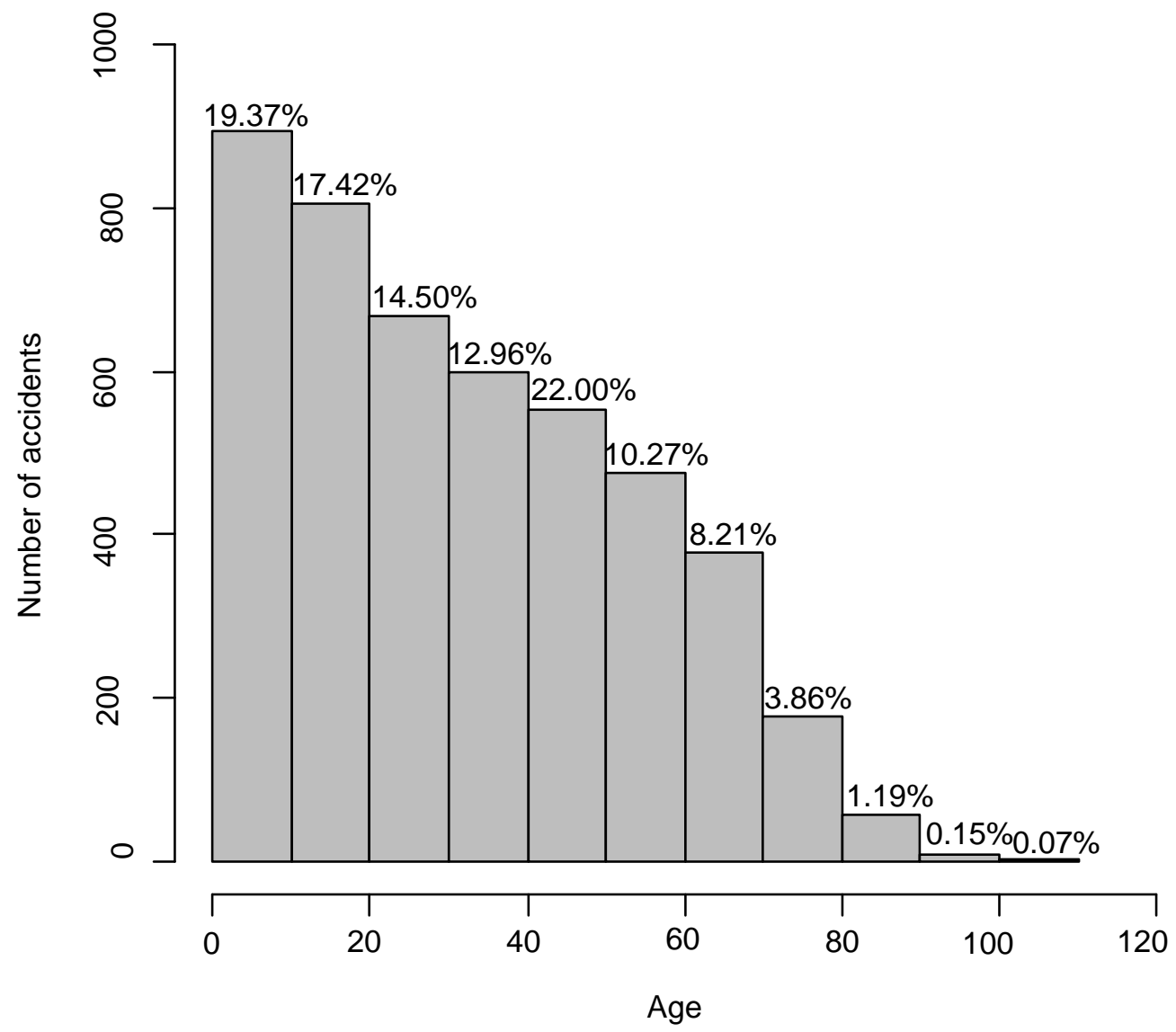

Source: De Matos IM, et al., 2020.

The upper limb was the sting site in $47.67 \%$ of victims, with $40.82 \%$ being the hand or fingers; $35.86 \%$ were stricken in the lower limbs, with the foot or toes being stung $25.92 \%$ of the time; $6.35 \%$ occurred in other parts of the body, and $10.12 \%$ of the sting site was ignored (Figure 3).

Figure 3 - Anatomical region of the scorpion sting.

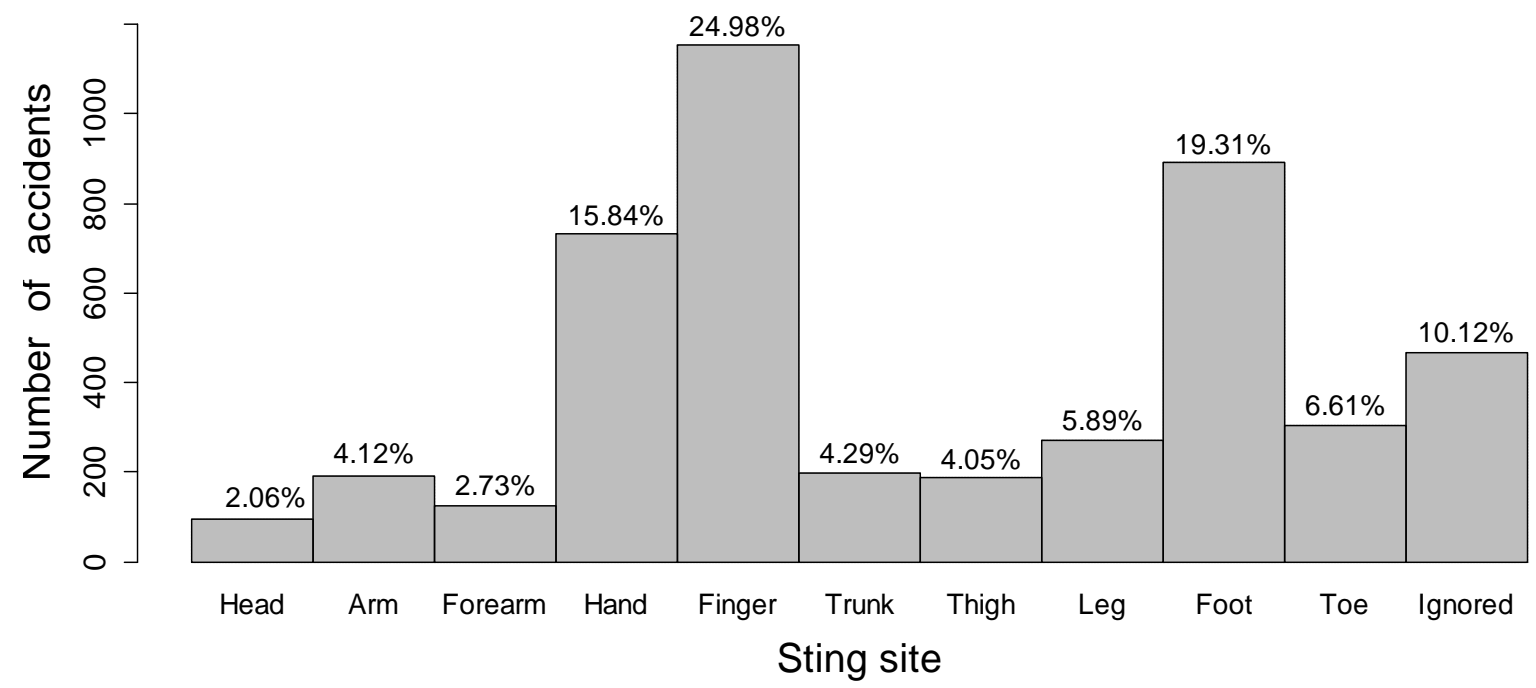

Source: De Matos IM, et al., 2020. 
From 3,877 people who reported the time between scorpion bite and hospitalization, 3,780 (97.5\%) were admitted to the hospital in less than 24 hours, with an average of 2.18 hours and a median of 2 hours with first and third quartile $(0.5-4.5)$ (Table 1).

Table 1 - Elapsed time between the sting and hospital admission.

\begin{tabular}{ccc}
\hline Hours & Number of accidents & Number of accidents (\%) \\
\hline $0-1$ & 1300 & 28.64 \\
$1-3$ & 1762 & 38.82 \\
$3-6$ & 521 & 11.48 \\
$6-12$ & 139 & 3.06 \\
$12-24$ & 58 & 1.28 \\
Over 24 & 97 & 2.14 \\
Unspecified & 662 & 14.58 \\
\hline
\end{tabular}

Source: De Matos IM, et al., 2020.

Regarding local and systemic clinical manifestations observed as a result of scorpion stings, the majority of patients $(98.04 \%$ ) had local pain, while $23,17 \%$ had local edema, $1.49 \%$ ecchymosis and $0.12 \%$ had necrosis. The most frequent systemic clinical manifestations were vagal manifestations $(81,76 \%)$ and the main systemic complications were pulmonary edema (100\%) and shock (67\%). Concerning rate mortality, all who experienced systemic complications died.

There were 9 deaths in children under 10 years old, 2 deaths in children 10 and 14 years old respectively and one patient aged 72 years died. In 10 patients who died, the time elapsed between the moment of the bite and the hospital care was one hour or more, of these, 6 patients care were 3 hours or more after the bite. Serotherapy was performed in 1622 patients (35,12\%) including all lethal cases, in 2940 cases $(63,66 \%)$ antivenom was not administered and in 56 cases $(1,22 \%)$ were not informed. Evolution for cure was predominant $(99,74 \%)$ (Table 2).

Table 2 - Number of clinical manifestations and scorpionism complications from 2007 to 2016.

\begin{tabular}{lrrrrrr}
\hline Variables & \multicolumn{2}{c}{ Yes } & \multicolumn{2}{c}{ No } & \multicolumn{3}{c}{ Ignored } \\
\hline Local manifestations & 4086 & $(88.83 \%)$ & 197 & $(4.28 \%)$ & 317 & $(6.89 \%)$ \\
Pain & 4008 & $(98.04 \%)$ & 60 & $(1.47 \%)$ & 20 & $(0.49 \%)$ \\
Edema & 947 & $(23.17 \%)$ & 2806 & $(68.66 \%)$ & 334 & $(8.17 \%)$ \\
Ecchymosis & 61 & $(1.49 \%)$ & 3656 & $(89.45 \%)$ & 370 & $(9.05 \%)$ \\
Necrosis & 5 & $(0.12 \%)$ & 3710 & $(90.78 \%)$ & 372 & $(9.10 \%)$ \\
Others & 55 & $(1.53 \%)$ & 3233 & $(90.13 \%)$ & 299 & $(8.34 \%)$ \\
Systemic manifestations & 592 & $(12.93 \%)$ & 3425 & $(74.78 \%)$ & 563 & $(12.29 \%)$ \\
Neuroparalytic & 20 & $(3.38 \%)$ & 547 & $(92.40 \%)$ & 25 & $(4.22 \%)$ \\
Vagal & 484 & $(81.76 \%)$ & 104 & $(17.57 \%)$ & 4 & $(0.68 \%)$ \\
Mio/hemolytic & 8 & $(1.35 \%)$ & 555 & $(93.75 \%)$ & 29 & $(4.90 \%)$ \\
Renal & 8 & $(1.35 \%)$ & 555 & $(93.75 \%)$ & 29 & $(4.90 \%)$ \\
Others & 160 & $(36.12 \%)$ & 269 & $(60.72 \%)$ & 14 & $(3.16 \%)$ \\
Systemic complications & 12 & $(100 \%)$ & 0 & $(0 \%)$ & 0 & $(0 \%)$ \\
Renal failure & 2 & $(17 \%)$ & 8 & $(67 \%)$ & 2 & $(17 \%)$ \\
Pulmonary edema & 12 & $(92 \%)$ & 0 & $(0 \%)$ & 1 & $(8 \%)$ \\
Septicemia & 0 & $(0 \%)$ & 8 & $(67 \%)$ & 4 & $(33 \%)$ \\
Shock & 8 & $(67 \%)$ & 2 & $(17 \%)$ & 2 & $(17 \%)$ \\
\hline
\end{tabular}

Source: De Matos IM, et al., 2020. 
Regarding the epidemiological characteristics, the places in Governador Valadares that showed higher incidences of scorpionism were urban area and the Chonin district with 1,815 and 152 cases respectively. In most of the neighborhoods, accidents ranged from 50 to 100, including the country side (77 incidents) and the Santo Antonio do Pontal district (60 incidents). Chonin and Santo Antonio do Pontal districts are 24.1 and 21.1 $\mathrm{km}$ away from the city center each. In urban area occurred 4 deaths, in nearby regions 5 and the other 3 deaths did not specify the place.

The adjusted linear regression model was, $Y=10.44 x-20827.49$, where $Y$ is the bite rate per 100,000 inhabitants and $x$ the year. This model was significant at the $5 \%$ level of significance ( $p$-value $=0.0038)$. The values observed and estimated for each year, shows an increasing trend in the bite index. Through this model, as of 2007, for each year that passes, it is estimated an average increase of approximately 10 bites per 100 thousand inhabitants (Figure 4).

Figure 4 - Bites index per 100,000 inhabitants for each year from 2007 to 2016.

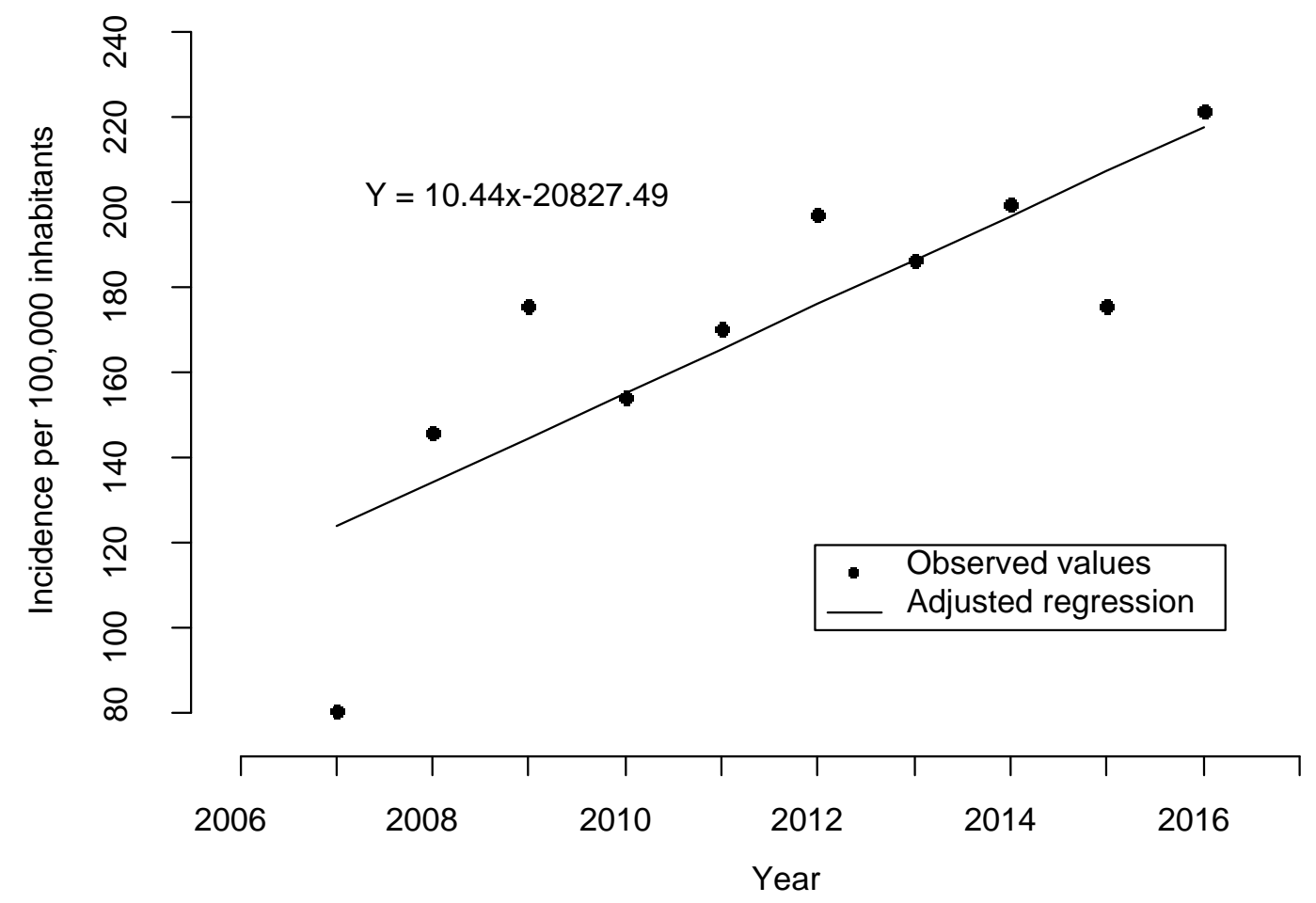

Source: De Matos IM, et al., 2020.

\section{DISCUSSION}

This study described and assessed the scorpion accidents reported and treated in a public hospital in east Minas Gerais, from January 2007 to December 2016. Data were collected from all medical records of patients showing a diagnosis of scorpionism. The results show that the age group from 0 to 14 years and over 70 years, the longer time elapsed from the moment of the sting and the hospital care, as well as to the severity of scorpionism are associated with a higher number of deaths.

The incidence of severe cases was $2 \%$, which was smaller when compared to others studies conducted in Brazil, that was 15.9\% in the years 2007 to 2015 (Jequié, Bahia) and 3.4\% in the years 2007 to 2013 (Ceará), respectively (CARMO EA, et al., 2019; FURTADO SS, et al., 2016).

The findings corroborate with data from the Ministry of Health (2001), which states that fatalities associated to scorpionism are mostly within the pediatric age group, up to the age of 14 years, which represents the most vulnerable age group. Elderly individuals have a weakened immune system, a fact that also contributes to mortality by scorpionism. It is known that several factors influence the severity of accidents caused by scorpions, among them, the species, the size of the scorpion, the quantity of inoculated venom, the affected 
body region, age and sensitivity of the victim to the animal's poison. Children and elderly people are a risk group. Pain at the site of the sting was present in nearly $100 \%$ of the patient reports. Vomiting and diarrhea were reported in the majority of the reports that stated systemic manifestations. All patients who presented systemic manifestations died, and the causes of death were acute pulmonary edema and/or shock. Cardiorespiratory manifestations, especially acute pulmonary edema and shock are the main causes of death in severe scorpion accidents (FIGUEIREDO AB, et al., 2010).

In a study carried out in Turkey in multivariate analysis, it was shown that age under 5 years is associated with a poor prognosis, because for the same amount of injected poison, the concentration of poison in the plasma may be higher in children than in adults. Other factors related to a poor prognosis are fever, coma and pulmonary edema (BOUAZIZ M, et al., 2008).

Regarding the age of the victims, the average value was 30 years, similar to what is shown in the São Paulo and Uberlândia studies, where the most affected age group is the 20-30 years' age group. In Pará, the most afflicted age group varied from those aged $33.6 \pm 18.3$ years to those with 20 to 39 years' age gap (NETO AM, et al., 2008; RIBEIRO AL, et al., 2001; SILVA FG, et al., 1999). The elapsed time between the accident and medical assistance was mostly between 0 and 3 hours. This matches the findings described in the scorpionism incidents in São Paulo and the northeast region, where medical care was provided within 3 hours after the accident, respectively. However, in Pará, the elapsed time ranged from 1 hour and 20 minutes until 7 hours and 48 minutes (RIBEIRO AL, et al., 2001; BARROS RM, et al., 2014; COSTA CLSO, 2012).

In Minas Gerais, among the cases involving children in the period from 2000 to 2005, it was demonstrated that, for every 1 -h elapsed between accident and medical assistance, the likelihood of death increased by $9 \%$ (GUERRA CM, et al., 2008). The longer the elapsed time between the sting and first aid, the greater the number of deaths (REZENDE NA, et al., 1998). Serotherapy is effective and applied by physicians in the country and abroad. In Brazil, scorpion antivenom serum treatment is important, given that the delay in its administration is directly related to lethality (GUERRA CM, et al., 2008). The Ministry of Health recommends that scorpion antivenom serum treatment must be given as soon as possible, and the dose must be adequate to neutralize all circulating venom to ensure rapid neutralization (REZENDE NA, et al., 1998; FOËX B and WALLIS L, 2005).

In this study, most victims did not undergo serum treatment, since mild cases do not require serotherapy. Nevertheless, the serum was administered in all lethal cases. These results are in agreement with those obtained by other authors (CUPO P, et al., 2003; PARDAL PPO, et al., 2003; BARBOSA AD, et al., 2012).

In the eastern region of Minas Gerais, although accidents occurred in all months of the year, they peaked in October, November, and December, which has the highest rainfall in the region, data that are in line with the indexes of the Hospital de Pronto-Socorro João XXIII in Belo Horizonte, where there is also an increase in the number of intoxications during the rainy season, from August to March (BARBOSA AD, et al., 2012). Tucumán is one of the provinces with the highest incidence of scorpion cases in Argentina. In this province the most number of cases occurred between the months of October and March, when the temperature is higher. It has been suggested that as a result of the phenomenon of global warming, there may have been an increase in the metabolic and reproductive rate of scorpions and their prey, especially cockroaches (EZQUER MR, et al., 2016).

Tucumán is one of the provinces with the highest incidence of cases of scorpionism in Argentina. In this province the largest number of cases occurre between the months october and March, with higher temperature and can be due to the behavior of the insect as a consequence of a global warming climate phenomenon: increases the metabolic and reproductive rate of scorpions and their prey (mostly cockroaches), heavy rains, flooding of underground habitats. Regarding sex, most victims were male during most of the period analyzed, which was similar to those in the studies conducted in São Paulo and Bahia (RIBEIRO AL, et al., 2001; AMORIM AMD, et al., 2003).

However, in Belém do Pará and the northeast part of Brazil, the highest number of incidents involved women (YAMANO EYS, et al., 1999; BARROS RM, et al., 2014). In Uberlândia, a city in Minas Gerais, there is no predominance of sex among the victims (SILVA FG, et al., 1999). Thus, there are differences in the 
predominance of sex among victims of scorpionism in the same state, demonstrating that each region has its peculiarities. This study is in accordance with what happens in different regions in Brazil.

This study shows that the upper limbs were more often stung compared to other parts of the body, which is analogous to what occurs in Ribeirão Preto and Belo Horizonte, São Paulo, and Pará (BÜCHERL W, 1969; RIBEIRO AL, et al., 2001; CUPO P, et al., 2003). It is different from the studies conducted in the Santarém region, Pará and the northeast part of the country, which demonstrated that the lower limbs were more prone to scorpion stings (COSTA CLSO, 2012; BARROS RM, et al., 2014). Studies in South Africa and Egypt support the findings of the Santarém and the northeast studies (MÜLLER GJ, 1993; FARGHLY WMA and ALI FAA, 1999).

Concerning the distribution of accidents involving scorpion envenomation in east Minas Gerais, it is observed that there were variations in the distances of the occurrences, which may indicate that the problem of scorpionism is scattered in the urban area, as well as demonstrating its high adaptability to urban environments and rapid proliferation (LOURENÇO WR, 2015). Soares MRM, et al. (2002) suggests that Zoonosis control programs should be applied continuously, year after year, and will only show positive results when the population shows behavioral changes that will be reflected in the decrease in accident rates. They claim that scorpionism is a basically socio-cultural and economic problem.

The fact that the species of scorpions that caused the accidents were not recorded in the medical records, the data were obtained from an instrument filled in by different professionals and the possible underreporting of cases are limitations of this study, as they may have contributed to generate information bias. However, patients generally do not take scorpions for identification when they are admitted to the hospital (CAMPOLINA D, 2006).

According to the center of Zoonoses of Governor Valadares (personal communication) there is a predominance of the scorpion $T$. serrulatus in the region and to a lesser extent the scorpion $T$. bahiensis. Based on this information, it is possible to assume that most accidents were caused by scorpion $T$. serrulatus. Despite these difficulties, this study is important because it reveals clinical and epidemiological aspects of scorpionism in east Minas Gerais, in addition to being the first study in the region.

\section{CONCLUSION}

In this study, we found that the accidents occurred in all months of the year, they peaked in October, November, and December, the most victims were male, the average value age of the victims was 30 years. The elapsed time between the accident and medical assistance was mostly between 0 and 3 hours, the majority victims did not undergo serum treatment. The upper limbs were more often stung compared to other parts of the body and the distribution of accidents shows variations in the distances of the occurrences. The incidence of severe cases was $2 \%$. The variables age, the elapsed time between the accident and medical care and the severity of symptoms played a pivotal role in death after poisoning by scorpion sting.

\section{REFERENCES}

1. AMARAL CFS, et al. Acute pulmonary edema after Tityus serrulatus scorpion sting in children. Am J Cardiol, 1993; 71(2): 242-5.

2. AMORIM AMD, et al. Acidentes por escorpião em uma área do Nordeste de Amaralina, Salvador, Bahia, Brasil. Rev Soc Bras Med Trop, 2003; 36(1): 51-56.

3. BARBOSA AD, et al. Caracterização dos acidentes escorpiônicos em Belo Horizonte, Minas Gerais, Brasil, 2005 a 2009. Cad Saúde Pública, 2012; 28(9): 1785-9.

4. BARROS RM, et al. Clinical and epidemiological aspects of scorpion stings in the northeast region of Brazil. Cien Saude Colet, 2014; 19(4): 1275-82.

5. BRASIL. Ministério da Saúde. Manual de diagnóstico e tratamento de acidentes por animais peçonhentos. Brasília: Fundação Nacional de Saúde, 2001; 2: 37.

6. BRASIL. Ministério da Saúde. Acidentes por animais peçonhentos - escorpião; dados 2000 a 2017,2017 [Internet]. Brasília: Ministério da Saúde; 201- [citado 2020 jan 27]. Disponível em: Disponível em: http://portalms.saude.gov.br/saude-de-a-z/acidentes-por-animais-peconhentos/13692-situacao-epidemiologicadados

7. BOUAZIZ M, et al. Epidemiological, clinical characteristics and outcome of severe scorpion envenomation in South Tunisia: Multivariate analysis of 951 cases. Toxicon, 2008; 52(8):918-26.

8. BÜCHERL W. Escorpionismo no Brasil. Mem Inst Butantan, 1969; 34: 9-24. 
9. CAMPOLINA D. Georreferenciamento e estudo clínico-epidemiológico dos acidentes escorpiônicos atendidos em Belo Horizonte, no serviço de toxicologia de Minas Gerais. M. Sc. Tese, Universidade Federal de Minas Gerais, 2006.

10. CAMPOS JA, et al. Signs, symptoms and treatments of severe scorpion sting in children. Toxicon, 1979; 17: 9.

11. CAMPOS JA, et al. Signs, symptoms and treatments of severe scorpion sting in children. In: Eaker D, Wadstrom T, editors. Natural toxins. Oxford: Pergamon, $1980 ; 66-8$

12. CARMO EA, et al. Factors associated with the severity of scorpio poisoning. Texto Contexto Enferm, 2019; 28 : e20170561

13. CHIPPAUX JP, GOYFFON M. Epidemiology of scorpionism: a global appraisal. Acta Trop, 2008; 107(2): 71-9.

14. COSTA BC. Fatores de risco para acidentes com escorpiões: uma revisão de literatura. Monografia (Especialização em Atenção Básica em Saúde da Família) - Universidade Federal de Minas Gerais. Faculdade de Medicina. 2011. $24 \mathrm{f}$.

15. COSTA CLSO. Aspectos Epidemiológicos do Escorpionismo na Região de Santarém, Estado do Pará, Brasil. Rev Colombiana Cienc Anim, 2012; 4(1): 59-68.

16. CUPO P, et al. Acidentes por animais peçonhentos: escorpiões e aranhas. Medicina (Ribeirão Preto), 2003; 36: 4907.

17. DE MATOS M, et al. Lung oedema induced by Tityus serrulatus scorpion venom in the rat. Comp Biochem Physiol, 1997; 11(2): 143-8.

18. DESHPANDE SB, AKELLA A. Non-cardiogenic mechanisms for the pulmonary edema induced by scorpion venom. Int J Cardiol, 2012; $157(3): 426-7$.

19. EZQUER MR et al. Scorpionism in children in Tucumán: descriptive analysis of cases in a second level of complexity Hospital. Arch Argent Pediatr 2016;114(6): e413-e416

20. FARGHLY WMA, ALI FAA. Clinical and neurophysiological study of scorpion envenomation in Assiut, upper Egypt. Acta Paediatr, 1999; 88: 290-4.

21. FIGUEIREDO AB, et al. Assessment of myocardial perfusion and function in victims of scorpion envenomation using gated-SPECT. Arq Bras Cardiol, 2010; 94(4): 418-25.

22. FOËX B, WALLIS L. Best evidence topic report. Scorpion envenomation: does antivenom reduce serum venom concentrations? Emerg Med J, 2005; 22: 195-7.

23. FURTADO SS, et al. Epidemiology of scorpion envenomation in the State of Ceará, Northeastern Brazil. Rev Inst Med Trop S Paulo, 2016; 58(15): 1-5.

24. GUERRA CM, et al. Analysis of variables related to fatal outcomes of scorpion envenomation in children and adolescents in the state of Minas Gerais, Brazil, from 2001 to 2005. J Pediatr (Rio J), 2008; 84(6): 509-15.

25. INSTITUTO BRASILEIRO DE GEOGRAFIA E ESTATÍSTICA - IBGE, 2019. Disponível em: https://www.ibge.gov.br/. Acesso em: 22 fev, 2020.

26. INSTITUTO BRASILEIRO DE GEOGRAFIA E ESTATÍSTICA - IBGE, 2014. Biblioteca IBGE. Disponível em: https://biblioteca.ibge.gov.br/. Acesso em: 27 ago, 2019.

27. INSTITUTO BRASILEIRO DE GEOGRAFIA E ESTATÍSTICA - IBGE, 2019. Ipea Data. Disponível em: http://www.ipeadata.gov.br/Default.aspx. Acesso em: 22 fev, 2019.

28. ISMAIL M. The scorpion envenoming syndrome. Toxicon, 1995; 33(7): 825-58.

29. LOURENÇO WR. What do we know about some of the most conspicuous scorpion species of the genus Tityus? A historical approach. J Venom Anim Toxins Incl Trop Dis, 2015; 21(1): 20-41.

30. MÜLLER GJ. Scorpionism in South Africa. A report of 42 serious scorpion envenomations. S Afr Med J, 1993; 83: 405-11.

31. NETO AM, et al. Aspectos do Escorpionismo no Estado do Pará - Brasil. Rev Para Med, 2008; 22(1): 49-55.

32. ORGANIZAÇÃO MUNDIAL DA SAÚDE. 2007. In: Rabies and Envenomings: A Neglected Public Health Issue: Report of a Consultative Meeting. Geneva: OMS. Disponível em: http://www.who.int/bloodproducts/animal_sera/Rabies.pdf2. Acesso em: 7 jan. 2017

33. PARDAL PPO, et al. Aspectos epidemiológicos e clínicos do escorpionismo na região de Santarém. Estado do Pará, Brasil. Rev Soc Bras Med Trop, 2003; 36: 349-53.

34. PIMENTA RJG, et al. Selected to survive and kill: Tityus serrulatus, the Brazilian yellow scorpion. PLoS ONE, 2019; 14(4): e0214075.

35. PUCCA MB, et al. Tityus serrulatus venom-A lethal cocktail. Toxicon, 2015; 108: 272-84.

36. RECKZIEGEL GC, PINTO JR VL. Scorpionism in Brazil in the years 2000 to 2012. J Venom Anim Toxins Incl Trop Dis, $2014 ; 20(46): 1-8$.

37. REZENDE NA, et al. Immunotherapy for scorpion envenoming in Brazil. Toxicon, 1998; 36: 1507-13.

38. RIBEIRO AL, et al. Aspectos clínicos e epidemiológicos do envenenamento por escorpiões em São Paulo e municípios próximos. Rev Patol Trop, 2001; 30: 83-92.

39. RIGONI VLS, et al. Human bronchial epithelial cells injury and cytokine production induced by Tityus serrulatus scorpion venom: An in vitro study. Toxicon, 2016; 120: 22e28.

40. SILVA FG, et al. Acidentes por escorpião: avaliação epidemiológica e clínica de 764 casos do HC-UFU de 1987 a 1996. Rev Soc Bras Med Trop, 1999; 32(supl I): 385

41. SOARES MRM, et al. Scorpionism in Belo Horizonte, MG: a retrospective study. Revista da Sociedade Brasileira de Medicina Tropical 2002; 35(4): 359-363.

42. YAMANO EYS, et al. Aspectos epidemiológicos e Clínicos dos acidentes por escorpiões orientados pelo Centro de Informações Toxicológicas de Belém, no período de maio de 1997 a novembro de 1998. Rev Soc Bras Med Trop, 1999; 32(supl I): 394.

43. ZOCCAL KF, et al. TLR2, TLR4 and CD14 recognize venom-associated molecular patterns from Tityus serrulatus to induce macrophage-derived inflammatory mediators. PloS ONE, 2014; 9: e88174. 